\title{
Best Practices of Promoting a Positive School Learning Climate among Principals of Cluster Secondary Schools Towards Realization of Education Blueprint 2013-2025 Malaysia
}

\author{
Mohamad Johdi Salleh \\ International Islamic University Malaysia (IIUM), Gombak \\ Muhammad Hatta \\ University Negeri of Acheh Indonesia
}

\begin{abstract}
The purpose of the study was to investigate the best practices of promoting a positive school learning climate among principals of Cluster Secondary Schools Malaysia according to principals' and teachers' perceptions. The Principal Instructional Management Rating Scale (PIMRS) modified by Hallinger and Murphy (1987), Latip (2006), Hatta (2010), Surayya (2016) was used as the data collection instrument through survey questionnaire. There were 871 respondents of different genders, ethnics, type of schools, and, position of responsibilities at schools were participated. The result of the study shows that the highest score was on dimension 'Developing and Enforcing Academic Standards' with mean 4.290 and standard deviation 0.814. It was followed respectively by 'Providing Incentives for Learning' mean 4.060 and standard deviation 0.904; 'Protecting Instructional Time' mean 3.855 and standard deviation 0.963 and 'Providing Incentives for Teachers' mean 3.607 and standard deviation 1.095. Meanwhile, the two best statements practiced by the principals were 'Use assemblies to honor students for their academic work and/or behavior in classroom' mean 4.39 and 'Encourage teachers to start class on time and teach to the end of the period' mean 4.38. It is hoped that this study will provide useful findings which will effectively assist the process of promoting a positive school learning climate among principals and teachers of secondary schools. Consequently, facilitate and improve students' academic performance in achieving the first class human capital who compatibly excellent nationally and internationally as stipulated in the purpose of establishing the Cluster Secondary schools by the Ministry of Education towards realization of Vision 2020 and the Education Blueprint 2013-2025 Malaysia.
\end{abstract}

Keywords: Principals' best practices - positive school learning climate - high performing secondary schools

\section{AUTHOR/ RESEARCHER}

Mohamad Johdi Salleh is an Associate Professor at Kulliyyah of Education, International Islamic University Malaysia (IIUM), Gombak, Selangor. He possessed BA Hons. (Malaya), MA Education (London), and, PhD Education (Birmingham). His area of specialization and interest are Leadership \& Educational Administration, Teacher Professionalism, and, History Education \& Citizenship

Email: johdi@iium.edu.my

\section{INTRODUCTION}

Principals who are accessible positively to the teachers and students contribute to a conducive climate for high school performance in various programmes includes academic, curriculum, cocurriculum, teachers' commitment, and, students' achievements. Harris and Lowery (2002) admitted, principals who take extra time to praise students for their achievements over the 
intercom, in the newspaper, or with personal notes and e-mails create a positive school climate. The positive commitments of principals would develop harmony, creative, constructive, innovative, and, transformative environment to school which greatly contribute to promulgate Cluster school performance towards realizing the Education Blueprint 20132025 (Ministry of Education Malaysia, 2012).

\section{Promoting a Positive School Learning Climate}

\section{LITERATURE REVIEW}

The positive school learning climate refers to the norms and attitudes of the staff and students that influence learning in the school. This dimension consists of primarily indirect, though important, activities. The principal communicates expectations for students and teachers through the policies and practices promulgated by the school (Allen, Grigsby \& Peters 2015).

The changing demands on schools in the twenty-first century require leaders who can challenge staff to mobilize their energies and adapt to changing requirements while controlling the stability and efficiency of the school organization as a whole. Leaders need to respond to the needs of diverse populations while maintaining high standards for instruction, which result in high levels of achievement (Knoll, 2002). Meanwhile, leaders play a critical role in creating a school environment that ensures learning activities are relevant to students' needs in order to accomplish high achievement.

Mc Carley, Peters \& Decman (2016) in their recent studies have documented that student achievement is strongly influenced by principals. The study claimed that schools really can make a difference in the achievement levels of students, but a school is most often only as good or bad, as creative or sterile, as the person who serves as the head of that school. O'Malley, Voight, Renshaw, \& Eklund (2015) observed that the Principals of effective schools are strong instructional leaders who know how to manage time and money effectively. They concentrate on priority goals and have high expectations for all students.

The above discussion shows that the Principals can influence student and teacher attitudes through the creation of a reward structure that reinforces academic achievement and productive effort; through clear, explicit standards embodying what the school expects from students; through the careful use of school time; and through the selection and implementation of high-quality staff development programmes.

Hallinger and Murphy (1987), Latip (2006), Muhammad Hatta (2010), and, Surayya (2016) affirmed that principals foster effectively the 'development of a positive school learning climate' conducive to teaching and learning as stipulated in the Instructional Leadership through the functions of 'protecting instructional time', 'providing incentives for teachers', 'developing and enforcing academic standards', and, 'providing incentives for learning'.

\section{Protecting Instructional Time}

Hallinger and Murphy (1987) stated that the principal should ensure the importance of providing teachers with blocks of uninterrupted instructional time. Teachers' classroom management and instructional skills are not used optimally if instruction is frequently interrupted by announcements, tardy students, and requests from the office.

The principal can control this area of activity through the development and enforcement of schoolwide policies. Principals who successfully implement policies that limit interruptions of classroom learning time can increase allocated learning time and, potentially, student achievement (Mohamad Johdi Salleh \& Muhammad Hatta. (2011). 
According to Ginsberg and Murphy (2002), principals need to regularly visit the classroom. Through these visits (i) principals become more familiar with the school's curriculum and teachers' instructional practices; (ii) principals can gauge the climate of a school: (iii) principals and teachers can examine instruction, student motivation and achievement together; (iv) principals establish themselves as campus leaders and instructional mentors, influencing teaching, learning, and ongoing school renewal; (v) students see that both the principal and teachers value instruction and learning.

Therefore, protecting instructional time is an important task of the principal as instructional leader in order to enable him/her to ensure that the teaching and learning process is running well and to ensure that at times in each classroom both teaching and learning process are taking place.

\section{Providing Incentives for Teachers}

Hallinger and Murphy (1987) emphasized that an important part of the principal's role in creating a positive learning climate involves setting up a work structure that rewards and recognizes teachers for their efforts.

Bear , Yang \& Pasipanodya (2015) admitted that Principals have few discretionary rewards to use with teachers. The single salary schedule and the tenure system severely limit principals' ability to motivate teachers. However, there are many forms of reward that are available to principals such as privately expressed praise, public recognition, and formal honours and awards. Meanwhile, incentive here does not mean that the principal should provide money to motivate teachers in performing their duties.

Blasé and Blasé (2000) provided a partial answer by asking teachers to describe the behaviour of principals who had a positive influence on student learning. Two broad themes emerged: talking with teachers and promoting professional development. These were expressed in specific types of behaviour such as making suggestions, giving feedback, modeling effective instruction, soliciting opinions, supporting collaboration, providing professional development opportunities, and giving praise for effective teaching (Mc Carley, Peters \& Decman, 2016).

All these actions were carried out in a way that respected teacher knowledge and autonomy.

\section{Developing and Enforcing Academic Standards}

Clearly defined, high standards reinforce the high expectations necessary for improving student learning. One study that compares successful and less successful schools found that successful schools tended to require mastery of a defined set of skills prior to entry into the following grade. High standards are also promoted when increasing numbers of students are expected to master basic skills (Hallinger \& Murphy, 1987).

Jamentz (2002) notes that principals must be able to recognize whether lessons are aligned with standards, develop classroom assessments consistent with standards, and evaluate student work for evidence that standards have been achieved. Hoy \& Hoy (2006) state that establishing a climate that promotes academic press has many benefits to the teaching and learning process. Quinn (2002) noted that a qualitative study of eight elementary schools indicated that schools which focus the climate around high expectations, high achievable standards, and an orderly, serious environment, have a positive impact on teacher instruction.

Teachers who work in a school with high academic press are more likely to use a variety of instructional strategies, plan diverse lessons to attend to different learning styles, monitor and 
provide feedback on student progress more frequently, collaborate with colleagues, demonstrate collegial behaviour, and attend to their own professional learning (Mohamad Johdi, 2014).

This is a proved that leaders have a deeper and more lasting influence on organizations and provide more comprehensive leadership if their focus extends beyond maintaining high standards.

\section{Providing Incentives for Learning}

According to Noddings (1992), schools, like families, are multipurpose institutions. Although academics are the focus of schools, students need adults to care about their personal interests. To meet this need, according to Harris and Lowery (2002), the principal can be accessible to students; reward them; be an advocate for them; and provide them with a safe, secure learning environment.

Hallinger \& Murphy (1987) admitted that the principal is a key actor in linking classrooms and school reward systems, ensuring that they are mutually supportive. Principals who are accessible to the students contribute to a positive climate for students. Harris and Lowery (2002) also mentioned that principals who take extra time to praise students for their achievements over the intercom, in the newspaper, or with personal notes and e-mails create a positive school climate.

McEwan (2003) and 0'Malley, Voight, Renshaw \& Eklund (2015) stated, four job functions constitute the conceptual definitions for the principal variables examined in this study. These definitions will be used to help generate the specific policies, practices, and behaviour that form the questionnaires which will be used to collect data on the practice of Promoting a Positive School Learning Climate of Instructional Leadership among principals of Cluster Secondary Schools Malaysia.

\section{AIM OF THE STUDY}

The purpose of this study was to investigate the best practices of promoting a positive school learning climate among principals of Cluster Secondary Schools Malaysia according to principals' and teachers' perceptions towards realization of Education Blueprint 2013-2015.

\section{Research Questions}

Research Question 1:

What is the Best Practice of Protecting Instructional Time among Principals of Cluster Secondary Schools Malaysia according to Principals and Teachers Perceptions?

\section{Research Question 2:}

What is the Best Practice of Providing Incentives for Teachers among Principals of Cluster Secondary Schools Malaysia according to Principals and Teachers Perceptions?

\section{Research Question 3:}

What is Best Practice of Developing and Enforcing Academic Standards among Principals of Cluster Secondary Schools Malaysia according to Principals' and Teachers' Perceptions?

\section{Research Question 4:}

What is the Best Practice of Providing Incentives for Learning among Principals of Cluster Secondary Schools Malaysia according to Principals' and Teachers' Perceptions? 


\section{Research Question 5:}

What is the Best Practice of Promoting a Positive School Learning Climate among Principals of Cluster Secondary Schools towards Realization of Education Blueprint 2013-2025 Malaysia?

\section{RESEARCH METHODOLOGY}

The Principal Instructional Management Rating Scale (PIMRS) modified by Hallinger and Murphy (1985), Latip (2006), Hatta (2010), Surayya (2016) was used as the data collection instrument through survey questionnaire. The list of cluster secondary schools was acquired from the Ministry of Education Malaysia. There were 871 respondents of different genders, ethnics, type of schools, and, position of responsibilities at schools were participated. The data was analyzed by using the Statistical Package for Social Science (SPSS) version 18. The result of the study was using 5-Likert-Scale that is Key: $\mathrm{N}=1$-Never; $\mathrm{S}=2$-Seldom; $\mathrm{R}=3$ - Rarely; $\mathrm{F}=4$ Frequently; A =5- Always (Creswell, 2008). This research was funded by Fundamental Research Grant Scheme (FRGS), Ministry of Education, Malaysia. The distribution and responses to the questionnaire from the management and teachers of cluster secondary schools were extremely encouraging.

\section{DATA ANALYSIS \& FINDINGS}

The practices of Promoting a Positive School Learning Climate among principals of Cluster Secondary Schools towards realization of Education Blueprint 2013-2025 Malaysia are presented in the following sections respectively.

\section{Research Question 1:}

What is the Best Practice of Protecting Instructional Time among Principals of Cluster Secondary Schools Malaysia according to Principals' and Teachers' Perceptions?

Table 1 described in detail the frequency, percentage, mean, and, standard deviation of each task involved in the best practice of Protecting Instructional Time among principals of Cluster Secondary Schools Malaysia according to principals' and teachers' perceptions.

Table 1:

Practice of Protecting Instructional Time among Principals of Cluster Secondary Schools Malaysia according to the Principals and Teachers Perceptions $(\mathrm{N}=871)$

\begin{tabular}{|c|c|c|c|c|c|c|c|c|}
\hline \multirow[b]{2}{*}{ No. } & \multirow[b]{2}{*}{ Items } & \multicolumn{5}{|c|}{ Responses } & \multirow[b]{2}{*}{ Mean } & \multirow{2}{*}{$\begin{array}{l}\text { Std. } \\
\text { Dev. }\end{array}$} \\
\hline & & $\mathbf{N}$ & $\mathbf{S}$ & $\mathbf{R}$ & $\mathbf{F}$ & $\mathbf{A}$ & & \\
\hline 1. & Instructional time is not interrupted & $\begin{array}{c}20 \\
(2.3)\end{array}$ & $\begin{array}{c}49 \\
(5.6)\end{array}$ & $\begin{array}{c}218 \\
(25.0)\end{array}$ & $\begin{array}{c}341 \\
(39.2) \\
\end{array}$ & $\begin{array}{c}243 \\
(27.9)\end{array}$ & 3.85 & .969 \\
\hline 2. & $\begin{array}{l}\text { Students are not called to the office } \\
\text { during instructional time }\end{array}$ & $\begin{array}{c}31 \\
(3.6)\end{array}$ & $\begin{array}{c}64 \\
(7.3)\end{array}$ & $\begin{array}{c}238 \\
(27.3)\end{array}$ & $\begin{array}{c}357 \\
(41.0)\end{array}$ & $\begin{array}{c}181 \\
(20.80\end{array}$ & 3.68 & .997 \\
\hline 3. & $\begin{array}{l}\text { Truant students suffer specified } \\
\text { consequences for missing } \\
\text { instructional time }\end{array}$ & $\begin{array}{c}9 \\
(1.0)\end{array}$ & $\begin{array}{c}63 \\
(7.2)\end{array}$ & $\begin{array}{c}190 \\
(21.8)\end{array}$ & $\begin{array}{c}331 \\
(38.0)\end{array}$ & $\begin{array}{c}278 \\
(31.9)\end{array}$ & 3.93 & .957 \\
\hline 4. & $\begin{array}{l}\text { Visit classrooms to see that } \\
\text { instructional time is used for } \\
\text { learning }\end{array}$ & $\begin{array}{c}9 \\
(1.0)\end{array}$ & $\begin{array}{c}45 \\
(5.2)\end{array}$ & $\begin{array}{c}203 \\
(23.3)\end{array}$ & $\begin{array}{c}328 \\
(37.7)\end{array}$ & $\begin{array}{c}286 \\
(32.8)\end{array}$ & 3.96 & .928 \\
\hline & $\begin{array}{l}\text { Total } \\
\end{array}$ & & & & & & 3.855 & 0.963 \\
\hline
\end{tabular}

Key: N = Never; $\mathrm{S}$ = Seldom; R = Rarely; F = Frequently; A = Always

The finding of the study on Table 1 presented that the highest score on Protecting Instructional Time among Principals of Cluster Secondary Schools Malaysia according to Principals' and Teachers' Perceptions was extracted from item 4 'Visit classrooms to see that instructional time is used for learning' mean 3.96 and standard deviation 0.928 . The result was indicated by 
286 or $32.8 \%$ respondents selected 'Always', 328 or $37.7 \%$ respondents selected 'Frequently', 203 or $23.3 \%$ respondents selected 'Rarely', 45 or $5.2 \%$ respondents selected 'Seldom', and, 9 or $1.0 \%$ respondents selected 'Never'.

The second highest score was item 3 'Ensure that truant students suffer specified consequences for missing instructional time' with mean 3.93 and standard deviation 0.957. The finding was proved by 278 or $31.9 \%$ respondents selected 'Always', as high as 331 or $38.0 \%$ respondents selected 'Frequently', 190 or $21.8 \%$ respondents selected 'Rarely', 63 or 7.2\% respondents selected 'Seldom', and, 9 or $1.0 \%$ respondents 'Never'.

\section{Research Question 2:}

What is the Best Practice of Providing Incentives for Teachers among Principals of Cluster Secondary Schools Malaysia according to Principals' and Teachers' Perceptions?

Table 2 described in detail the frequency, percentage, mean score, and, standard deviation of each task involved in providing incentives for teachers among principals of High Performing Secondary Schools Malaysia according to the principals' and teachers' perceptions.

Table 2:

Practice of Providing Incentives for Teachers among Principals of Cluster Secondary Schools Malaysia according to Principals' and Teachers' Perceptions ( $\mathrm{N}=871)$

\begin{tabular}{|c|c|c|c|c|c|c|c|c|}
\hline \multirow[b]{2}{*}{ No. } & \multirow[b]{2}{*}{ Items } & \multicolumn{5}{|c|}{ Frequency/ Percentage } & \multirow[b]{2}{*}{ Mean } & \multirow[b]{2}{*}{$\begin{array}{l}\text { Std. } \\
\text { Dev. }\end{array}$} \\
\hline & & $\mathbf{N}$ & $\mathbf{S}$ & $\mathbf{R}$ & $\mathbf{F}$ & A & & \\
\hline 5. & $\begin{array}{l}\text { Reinforce superior performance by } \\
\text { teachers }\end{array}$ & $\begin{array}{c}39 \\
(4.5)\end{array}$ & $\begin{array}{c}87 \\
(10.0)\end{array}$ & $\begin{array}{c}218 \\
(25.0)\end{array}$ & $\begin{array}{c}320 \\
(36.7)\end{array}$ & $\begin{array}{c}207 \\
(23.8)\end{array}$ & 3.65 & 1.082 \\
\hline 6. & $\begin{array}{l}\text { Compliment teachers for their } \\
\text { performance }\end{array}$ & $\begin{array}{c}53 \\
(6.1)\end{array}$ & $\begin{array}{c}115 \\
(13.2)\end{array}$ & $\begin{array}{c}218 \\
(25.0)\end{array}$ & $\begin{array}{c}305 \\
(35.0)\end{array}$ & $\begin{array}{c}180 \\
(20.7)\end{array}$ & 3.51 & 1.137 \\
\hline 7. & $\begin{array}{l}\text { Acknowledge special performance } \\
\text { by teachers in their personnel files }\end{array}$ & $\begin{array}{c}58 \\
(6.7) \\
\end{array}$ & $\begin{array}{c}124 \\
(14.2) \\
\end{array}$ & $\begin{array}{c}234 \\
(26.9) \\
\end{array}$ & $\begin{array}{c}296 \\
(34.0) \\
\end{array}$ & $\begin{array}{c}159 \\
(18.3) \\
\end{array}$ & 3.43 & 1.138 \\
\hline 8. & $\begin{array}{l}\text { Reward special efforts by teachers } \\
\text { with opportunities for professional } \\
\text { development }\end{array}$ & $\begin{array}{c}11 \\
(1.3)\end{array}$ & $\begin{array}{c}92 \\
(10.6)\end{array}$ & $\begin{array}{c}194 \\
(22.3)\end{array}$ & $\begin{array}{c}302 \\
(34.7)\end{array}$ & $\begin{array}{c}272 \\
(31.2)\end{array}$ & 3.84 & 1.023 \\
\hline & Total & & & & & & 3.607 & 1.095 \\
\hline
\end{tabular}

Key: $\mathrm{N}$ = Never; $\mathrm{S}=$ Seldom; $\mathrm{R}=$ Rarely; F = Frequently; $\mathrm{A}=$ Always

The result of the study on Table 2 identified, the highest score for providing incentives for teachers was extracted from statement 8 'Reward special efforts by teachers with opportunities for professional development e.g. new roles or in-service training' which indicated that 302 respondents (34.7\%) selected 'Frequently', as high as 272 respondents (31.2\%) selected 'Always', 194 respondents (22.3\%) selected 'Rarely', 92 respondents (10.6\%) selected 'Seldom', and, only 11 respondents (1.3\%) selected 'Never' of a total 871 respondents.

Table 2 presented, the second highest score was item 5 'Reinforce superior performance by teachers in staff meetings, newsletters, or memos' which as high as 320 respondents (36.7\%) selected 'Frequently', 207 respondents (23.8\%) selected 'Always', 218 respondents (25.0\%) selected 'Rarely', 87 respondents (10.0\%) selected 'Seldom', and, 39 respondents (4.5\%) selected 'Never'.

\section{Research Question 3:}

What is the Best Practice of Developing and Enforcing Academic Standards among Principals of Cluster Secondary Schools Malaysia according to Principals' and Teachers' Perceptions? 
Table 3 determined in detail the frequency, percentage, mean score, and, standard deviation of each task involved in Developing and Enforcing Academic Standards among Principals of Cluster Secondary Schools Malaysia according to Principals' and Teachers' Perceptions.

Table 3:

Practice of Developing and Enforcing Academic Standards among Principals of Cluster Secondary Schools Malaysia according to Principals' and Teachers' Perceptions ( $N=871)$

\begin{tabular}{|c|c|c|c|c|c|c|c|c|}
\hline \multirow[b]{2}{*}{ No. } & \multirow[b]{2}{*}{ Items } & \multicolumn{5}{|c|}{ Frequency/ Percentage } & \multirow[b]{2}{*}{ Mean } & \multirow[b]{2}{*}{$\begin{array}{l}\text { Std. } \\
\text { Dev. }\end{array}$} \\
\hline & & $\mathrm{N}-1$ & $S-2$ & $\mathbf{R}-\mathbf{3}$ & F-4 & A-5 & & \\
\hline 9. & $\begin{array}{l}\text { Set high standards for the students } \\
\text { who are expected to master important } \\
\text { instructional objectives }\end{array}$ & $\begin{array}{c}3 \\
(0.3)\end{array}$ & $\begin{array}{c}17 \\
(2.0)\end{array}$ & $\begin{array}{c}165 \\
(18.9)\end{array}$ & $\begin{array}{c}295 \\
(33.9)\end{array}$ & $\begin{array}{c}391 \\
(44.9)\end{array}$ & 4.21 & .839 \\
\hline 10. & $\begin{array}{l}\text { Encourage teachers to start class on } \\
\text { time }\end{array}$ & $\begin{array}{c}3 \\
(0.3)\end{array}$ & $\begin{array}{c}12 \\
(1.4)\end{array}$ & $\begin{array}{c}109 \\
(12.5) \\
\end{array}$ & $\begin{array}{c}277 \\
(31.8) \\
\end{array}$ & $\begin{array}{c}470 \\
(54.0) \\
\end{array}$ & 4.38 & .781 \\
\hline 11. & $\begin{array}{l}\text { Make known what is expected of } \\
\text { students at different grade }\end{array}$ & $\begin{array}{c}2 \\
(0.2)\end{array}$ & $\begin{array}{c}10 \\
(1.1)\end{array}$ & $\begin{array}{c}113 \\
(13.0)\end{array}$ & $\begin{array}{c}304 \\
(34.9)\end{array}$ & $\begin{array}{c}442 \\
(50.7)\end{array}$ & 4.35 & .764 \\
\hline 12. & $\begin{array}{l}\text { Enforce a promotion standard } \\
\text { requiring mastery of grade- }\end{array}$ & $\begin{array}{c}5 \\
(0.6) \\
\end{array}$ & $\begin{array}{c}21 \\
(2.4) \\
\end{array}$ & $\begin{array}{c}163 \\
(18.7)\end{array}$ & $\begin{array}{c}270 \\
(31.0) \\
\end{array}$ & $\begin{array}{c}319 \\
(36.6) \\
\end{array}$ & 4.22 & .872 \\
\hline & Total & & & & & & 4.290 & 0.814 \\
\hline
\end{tabular}

The result of the study on Table 3 demonstrated, the highest score in Developing and Enforcing Academic Standards among Principals of Cluster Secondary Schools Malaysia according to Principals and Teachers Perceptions was extracted from item 64 'Encourage teachers to start class on time and teach to the end of the period'. Table 3 indicated, the mean score for item 10 was 4.38 and Standard Deviation 0.781. The score was contributed by 470 respondents (54.0\%) selected 'Always', 277 respondents (31.8\%) selected 'Frequently', 109 respondents (12.5\%) selected 'Rarely', 12 respondents (1.4\%) selected 'Seldom', and, only 3 respondents $(0.3 \%)$ selected 'Never'.

The second highest score displayed on Table 3 was extracted from item 11 'Make known what is expected of students at different grade levels' with mean 4.35 and Standard Deviation 0.764. The result was supported by 442 respondents (50.7\%) selected 'Always', 304 respondents (34.9\%) selected 'Frequently', 113 respondents (13.0\%) selected 'Rarely', 10 respondents (1.1\%) selected 'Seldom', and, only 2 respondents $(0.2 \%)$ selected 'Never'.

\section{Research Question 4:}

What is the Best Practice of Providing Incentives for Learning among Principals of Cluster Secondary Schools Malaysia according to Principals' and Teachers' Perceptions?

Table 4 presented in detail the frequency, percentage, mean score, and, standard deviation of each task involved in Developing and Enforcing Academic Standards among Principals of Cluster Secondary Schools Malaysia according to Principals' and Teachers' Perceptions. 
Table 4:

Practice of Providing Incentives for Learning among Principals of Cluster Secondary Schools Malaysia according to the Principals and Teachers Perceptions $(\mathrm{N}=871)$

\begin{tabular}{|c|c|c|c|c|c|c|c|c|}
\hline \multirow[b]{2}{*}{ No. } & \multirow[b]{2}{*}{ Items } & \multicolumn{5}{|c|}{ Frequency/ Percentage } & \multirow[b]{2}{*}{ Mean } & \multirow{2}{*}{$\begin{array}{l}\text { Std. } \\
\text { Dev. }\end{array}$} \\
\hline & & $\mathrm{N}-1$ & $S-2$ & $\mathbf{R}-\mathbf{3}$ & F-4 & A-5 & & \\
\hline 13. & $\begin{array}{l}\text { Recognize students who do } \\
\text { superior academic work with } \\
\text { formal rewards }\end{array}$ & $\begin{array}{c}1 \\
(0.1)\end{array}$ & $\begin{array}{c}30 \\
(3.4)\end{array}$ & $\begin{array}{c}133 \\
(15.3)\end{array}$ & $\begin{array}{c}244 \\
(28.0)\end{array}$ & $\begin{array}{c}463 \\
(53.2)\end{array}$ & 4.31 & .860 \\
\hline 14. & $\begin{array}{l}\text { Use assemblies to honor } \\
\text { students for their academic } \\
\text { work and behavior in classroom }\end{array}$ & $\begin{array}{c}0 \\
(00)\end{array}$ & $\begin{array}{c}18 \\
(2.1)\end{array}$ & $\begin{array}{c}105 \\
(12.1)\end{array}$ & $\begin{array}{c}267 \\
(30.7)\end{array}$ & $\begin{array}{c}481 \\
(55.2)\end{array}$ & 4.39 & .777 \\
\hline 15. & $\begin{array}{l}\text { Recognize superior student } \\
\text { achievement in the office with } \\
\text { their work products }\end{array}$ & $\begin{array}{c}13 \\
(1.5)\end{array}$ & $\begin{array}{c}68 \\
(7.8)\end{array}$ & $\begin{array}{c}236 \\
(27.1)\end{array}$ & $\begin{array}{c}318 \\
(36.5)\end{array}$ & $\begin{array}{c}236 \\
(27.1)\end{array}$ & 3.80 & .974 \\
\hline 16. & $\begin{array}{l}\text { Contact parents to communicate } \\
\text { improves student performance } \\
\text { in school }\end{array}$ & $\begin{array}{c}20 \\
(2.3)\end{array}$ & $\begin{array}{c}73 \\
(8.4)\end{array}$ & $\begin{array}{c}245 \\
(28.1)\end{array}$ & $\begin{array}{c}310 \\
(35.6)\end{array}$ & $\begin{array}{c}223 \\
(25.6)\end{array}$ & 3.74 & 1.006 \\
\hline & Total & & & & & & 4.060 & 0.904 \\
\hline
\end{tabular}

Key: N = 1-Never; $\mathrm{S}=2$-Seldom; $\mathrm{R}=3$ - Rarely; $\mathrm{F}=4$-Frequently; $\mathrm{A}=5$ - Always

The result of the study on Table 4 revealed, the highest score in Providing Incentives for Learning among Principals of Cluster Secondary Schools Malaysia according to the Principals and Teachers Perceptions was extracted from item 14 'Use assemblies to honor students for their academic work and/or behavior in class' with mean 4.39 and Standard Deviation 0.777. This was supported by 481 respondents (55.2\%) selected 'Always', 267 respondents (30.7\%) selected 'Frequently', 105 respondents (12.1\%) selected 'Rarely', 18 respondents (2.1\%) selected 'Seldom', and, none or $0 \%$ of the respondents selected 'Never'.

Table 4 presented, the second highest score was item 13 'Recognize students who do superior academic work with formal rewards such as an honor roll or mention in the principal's newsletter' with mean 4.31 and Standard Deviation 0.860. This was proven when 463 respondents (53.2\%) selected 'Always', 244 respondents (28.0\%) selected 'Frequently', 133 respondents (15.3\%) selected 'Rarely', 30 respondents (3.4\%) selected 'Seldom', and, only 1 respondent $(0.1 \%)$ selected 'Never'.

\section{Research Question 5:}

What is the Best Practice of Promoting a Positive School Learning Climate among Principals of Cluster Secondary Schools Towards Realization of Education Blueprint 2013-2025 Malaysia?

Table 5 shows the Best Practice of Promoting a Positive School Learning Climate among Principals of Cluster Secondary Schools Malaysia. 
Table 5:

Practice of Promoting a Positive School Learning Climate

among Principals of Cluster Secondary Schools Malaysia ( $=871)$

\begin{tabular}{|l|c|c|c|c|}
\hline \multicolumn{1}{|c|}{ Functions } & Mean & $\begin{array}{c}\text { Standard } \\
\text { Deviation }\end{array}$ & Practice & Rank \\
\hline Protecting Instructional Time & 3.855 & 0.963 & High & 3 \\
\hline Providing Incentives for Teachers & 3.607 & 1.095 & High & 4 \\
\hline Developing and Enforcing Academic Standards & 4.290 & 0.814 & Very High & 1 \\
\hline Providing Incentives for Learning & 4.060 & 0.904 & Very High & 2 \\
\hline Total & $\mathbf{3 . 9 5 3}$ & $\mathbf{0 . 9 4 4}$ & High & \\
\hline
\end{tabular}

Key: $\mathrm{N}=1$-Never; $\mathrm{S}=2$-Seldom; $\mathrm{R}=3$ - Rarely; $\mathrm{F}=4$-Frequently; $\mathrm{A}=5$ - Always

Practice: Low = 1.00-1.99; Simple High 2.00-2.99; High = 3.00-3.99; Very High = 4.00- 5.00.

Table 5 indicates, the best practice of Promoting a Positive School Learning Climate among Principals of Cluster Secondary Schools Malaysia was on dimension 'Developing and Enforcing Academic Standards' mean 4.226 and standard deviation 0.840, implemented at a 'Very Hugh' level. It was respectively followed by dimensions 'Providing Incentives for Learning' mean 4.060 and standard deviation 0.904 which was implemented at a 'Very High' level, 'Protecting Instructional Time' mean 3.788 and standard deviation that was implemented at a 'High' level, and, finally 'Providing Incentives for Teachers' mean 3.607 and standard deviation 1.095, implemented at a 'High' level.

\section{SUMMARY AND DISCUSSION \\ Best Practice of Promoting a Positive School Learning Climate among Principals of Cluster Secondary Schools Towards Realization of Education Blueprint 2013-2025 Malaysia.}

The study demonstrated that the best practice of Promoting a Positive School Learning Climate among Principals of Cluster Secondary Schools Malaysia according to Principals' and Teachers' Perceptions was on dimension 'Developing and Enforcing Academic Standards' mean 4.226 and standard deviation 0.840 .

The 'Very High' practice of dimension 'Developing and Enforcing Academic Standards' was significant to the realization of 'System Aspiration' stipulated in the Education Blueprint 2013 - 2025. There are five outcomes that this Blueprint aspires to for the Malaysian education system as a whole namely access, quality, equity, unity, and efficiency. The 'Very High' practice of excellent secondary schools' principals on Item 9 'Set high standards for the percentage of students who are expected to master important instructional objectives' mean 4.21 and standard deviation 0.839 was significant to realize the Blueprint 'quality' aspiration of 'All children will have the opportunity to attain an excellent education that is uniquely Malaysian and comparable to the best international systems'.

Another 'Very High' practice of Cluster secondary schools' principals on item 11 'Make known what is expected of students at different grade levels' mean 4.35 and standard deviation 0.764 was prominently congruent to the Blueprint 'equity' aspiration of 'Top-performing school systems deliver the best possible education for every child, regardless of geography, gender, or socioeconomic background. The Ministry aspires to halve the current urban-rural, socioeconomic, and gender achievement gaps by 2020 '.

The principals of Cluster secondary schools 'Very High' practice on item 10 'Encourage teachers to start class on time and teach to the end of the period' mean 4.38 and standard deviation 0.781 really significant to achieve the Blueprint 'unity' aspiration 'As students spend over a quarter of their time in school from the ages of 7 t0 17, schools are in a key position to 
foster unity. Through interacting with individuals from a range of socioeconomic, religious, and ethnic backgrounds-and learning to understand, accept and embrace differences-a shared set of experiences and aspirations for Malaysia's future can be built. The Ministry aspires to create a system where students have opportunities to build these shared experiences and aspirations that form the foundation for unity'.

The Best Practice of Providing Incentives for Learning among Principals of Cluster Secondary Schools Malaysia according to the Principals and Teachers Perceptions achieved mean 4.060 and standard deviation 0.904 . This 'Very High' level practice of principals was significant factor to realize the Blueprint Student Aspirations that beyond these system-wide outcomes, stakeholders were also very clear on what 'quality' should be at the individual level. In a nutshell, educators, parents, students, and other members of the public were united in a vision of education as a vehicle for the holistic development of children-intellectually, spiritually, emotionally, and physically. This is the same vision that has underscored all education improvement efforts since the National Education Philosophy for Malaysia was written in 1988 (Mohamad Johdi, 2014).

Looking ahead, the Blueprint will continue to use the National Education Philosophy's vision of a balanced education as its foundation for individual student aspirations. It has also drawn on learning from other high-performing systems to develop a refined articulation of the specific skills and attributes that students would need to thrive in tomorrow's economy and globalised world. (Ministry of Education Malaysia, 2012).

The above dimension was supported by the principals 'Very High' practice on item 13 'Recognize students who do superior academic work with formal rewards such as an honor roll or mention in the principal's newsletter' mean 4.31 and standard deviation 0.860. Another contribution of the realization was principals' Very High' practices on item 14 'Use assemblies to honor students for their academic work and/or behavior in class' mean 4.39 and standard deviation 0.777. Consequently, both items are significant to the Blueprint Student Aspiration on 'access' that 'Every child in Malaysia deserves equal access to an education that will enable that child to achieve his or her potential. The Ministry thus aspires to ensure universal access and full enrolment of all children from preschool through to upper secondary school level Form 5 by 2020 .

The study suggest that the very high practice of principals of excellent secondary schools are significant factor to realize the Blueprint Student aspiration in Knowledge, Thinking Skills, Leadership skills, Bilingual Proficiency, Ethics and Spirituality, and, National identity. The findings were prominently relevant and significant to realize the Ministry of Education 11 shifts which require the most urgent attention. Some of these shifts represent a change in strategy, direction and represent a move away from current practices (Ministry of Education, Malaysia, 2012).

Collectively, these aspirations and shifts address every stakeholder and the main concerns of the public. The Ministry hopes that this inclusiveness will provide the basis for a common focus that can be embraced by all Malaysians.

\section{CONCLUSION}

In fact, the most important and the most difficult job of an instructional leader is to change the prevailing culture of a school. A school's culture has far more influence on life and learning in the schoolhouse than the president of the country, the state department of education, the superintendent, the school board, or even the principal, teachers, and parents can ever have. 
One cannot, of course, change a school culture alone. But one can provide forms of leadership that invite others to join as observers of the old and architects of the new. Meanwhile, the principal must ensure all the elements within school, especially something which challenges the teaching and learning process.

It is hoped that this study provides useful findings which will effectively assist the process of promoting a positive school learning climate among principals and teachers of secondary schools in Malaysia. Consequently, facilitate and improve students' academic performance in achieving the first class human capital compatibly excellent nationally and internationally as stipulated in National Philosophy of Education, Vision 2020 and aspiration of the Malaysia Education Development Plan 2013-2025.

\section{References:}

Allen, N., Grigsby, B., \& Peters, M. L. (2015). Does Leadership Matter? Examining the relationship between Transformational Leadership, School Climate, and, Students' achievements. International Journal of Educational Leadership Preparation,10 (2), 1-22.

Bear, G. G., Yang, C., \& Pasipanodya, E. (2015). Assessing School Climate Validation of a Brief Measure of the Perceptions of Parents. Journal of psych educational assessment, 33(2), 115-129.

Blasé, J. \& Blasé, J. (2000). Effective instructional leadership: Teachers perspective on how principals promote teaching and learning in schools. Journal of Educational Administration, 38(2), 130-141.

Creswell, J. W. (2008). Educational Research. (2nd ed). New Jersey: Prentice Hall

Ginsberg, M.B., \& Murphy, D. (2002). How walkthroughs open doors. Educational Leadership 59(8), 34-36.

Hallinger, P., \& Murphy, J. (1987). Assessing and developing principal instructional leadership. Educational Leadership 45(1), 54-61.

Harris, S.L., \& Lowery, S. (2002). A view from the classroom. Educational Leadership 59(8), 64-66.

Hatta, Muhammad. (2010). Relationship between Principals' Instructional Leadership Practices and Students' Academic Achievement of Secondary Schools in Banda Acheh, Indonesia. Thesis - Master of Education, Institute of Education, International Islamic University Malaysia (IIUM).

Hoy, A.W., \& Hoy, W.K. (2006). Instructional leadership: A learning-centered guide. (2nd ed). Boston: Pearson.

Jamentz, K. (2002). Isolation is the enemy of improvement: Instructional leadership to support standards-based practice. San Francisco: WestEd.

Knoll, M.K. (2002). Administrator's guide to student achievement \& higher test scores. USA: Prentice Hall.

Latip Muhammad (2006). Pelaksanaan kepemimpinan pengajaran di kalangan pengetua sekolah di negeri Selangor Darul Ehsan. Tesis Doktor Falsafah, Fakulti Pendidikan, Bangi: Universiti Kebangsaan Malaysia.

Mc Carley, T. A., Peters, M. L., \& Decman, J. M. (2016). Transformational leadership related to school climate a multi-level analysis. Educational Management Administration \& Leadership, 44(2), 322-342.

McEwan, E. K. (2003). Seven steps to effective instructional leadership. (2nd ed.). California: Corwin Press, Inc. Ministry of Education, Malaysia. (2012). Malaysia Education Blueprint 2013-2025. Putrajaya: Ministry of Education Malaysia.

Mohamad Johdi Salleh. (2014). Best Practice Of Framing And Communicating School Goals Among Principals Of Cluster Secondary Schools Towards Realization Of Malaysian Education Blueprint 2013-2025. The International Journal of Social Sciences and Humanities Invention. Volume 1 issue 62014 pp.458-466 ISSN: 2349-2031.

Mohamad Johdi Salleh \& Muhammad Hatta. (2011). Major Theories of Instructional Leadership. In Hairudin, Azam \& Mohamad Johdi (2011) Educational Leadership and Management. Kuala Lumpur: IIUM Press. ISBN 978-967418-013-3)

O’Malley, M., Voight, A., Renshaw, T. L., \& Eklund, K. (2015). School climate, family structure, and academic achievement: A study of moderation effects. School Psychology Quarterly, 30(1), 142

Quinn, D.M. (2002). The impact of principal leadership behaviors on instructional practice and student engagement. Journal of Educational Administration 40(5), 447-467. 